\title{
Naturhistorisk Guide - ny spcendende hjemmeside
}

\section{Af geolog Ulla Vibeke Hjuler, GeologiskNyt}

En ny og informativ naturhistorisk hjemmeside samler en masse gode links til hele spektret af naturvidenskab. Her får man lynhurtigt en masse gode informationer.

Hvis man gerne vide noget om for eksempel fiskeri og ressourcer - men ikke ved, hvad der findes om emnet, kunne man tage et kig på hjemmesiden under tidsskrifter. Her findes en god liste, hvor forskellige naturvidenskabelige magasiner er beskrevet - desuden er der andre relevante oplysninger om bl.a. hjemmesider, abonnementspriser og lignende.

\section{Oversigt over centre og tilsvarende} En god liste med muligheder for mange timers oplevelser finder man under overskriften "Botaniske og zoologiske haver og akvarier". Her kan man læse mere om eksempelvis Danmarks Akvarium, hvor særudstillinger, permanente udstillinger, oplysninger om rundvisninger samt relevante informationer som åbningstider og adresse er anført.

\section{Foreninger og hjemmesider}

En ganske omfangsrig liste frister læseren med et bredt udvalg af forskellige naturhistoriske foreninger under oversigten "Foreninger og organisationer" - lige fra Lepidopterologisk Forening (der beskæftiger sig med danske sommerfugle) til DAGU, (Dansk AmatørGeologisk Union).

Også listen med mere end 30 links over relevante hjemmesider kan sende læseren til spændende websteder inden for naturvidenskabens verden.

\section{Initiativtageren}

Det er formanden for Naturhistorisk For-

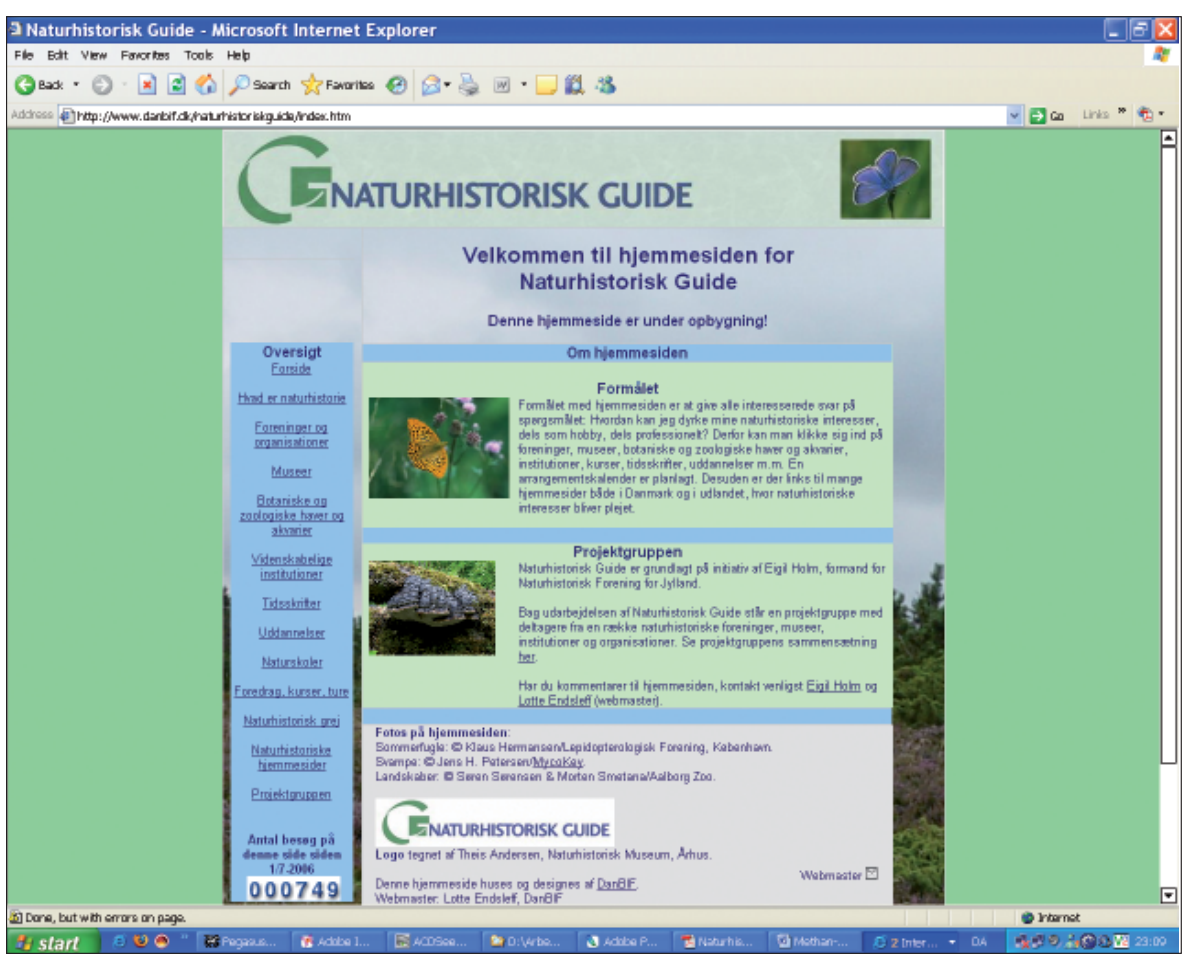

Skcrmdump af hjemmesidens forside.

ening for Jylland, Eigil Holm, der har taget initiativet til oprettelsen af hjemmesiden. Eigil Holm har sit eget forlag og har udgivet 65 bøger. Han er biolog, geolog og geograf. Desuden er han formand for "Horsens - Ren Fjord" samt for "Naturforeningen i Gedved Kommune". På hjemmesiden: www.eigilholm.dk kan man læse mere om initiativtageren og hans mange projekter.

Det er biolog, PR \& Scientific Liaison Officer, DanBIF (Danish Biodiversity Information Facility), Lotte Endsleff, der har stået for udarbejdelsen af den fornemme hjemmeside.

Hjemmesiden er stadig under udarbejdelse, men der er allerede så meget at se på,

\section{Vidste du}

*At du i hele december måned kan købe alle de tidligere, ikke-udsolgte numre (p.t. 65 stk.) for kun $300 \mathrm{kr}$. (ekskl. porto 63,00 kr.)?
*At du i hele december måned 2006 kan forære dig selv eller en bekendt et abonnement på GeologiskNyt til kun 220 kr.? at man ikke kommer til at kede sig! Kig på www.danbif.dk/naturhistoriskguide

\section{Webadresse:}

www.danbif.dk/naturhistoriskguide

\section{Relevante links mv. modtages gerne!}

Hvis du har et relevant link, et spændende kursus eller en forening, du mener, der kan være relevant at få opført på denne hjemmeside, kan du kontakte:

Eigil Holm: eigil.holm@pc.dk (Initiativtager til Naturhistorisk Guide)

Lotte Endsleff: lendsleff@snm.ku.dk (Webmaster for Naturhistorisk Guide) 